\title{
Applying Solow Model To Measure The Appropriate Capital Stock And The Contribution Of Productivity To The Economic Growth In Lebanon, Jordan, Egypt, And Syria \\ Viviane Y. Naïmy, (Email: vnaimy@aud.edu), American University in Dubai, U.A.E.
}

\begin{abstract}
The productivity contribution to economic growth has never been measured in Lebanon, Jordan, Egypt, or Syria. This paper measures the contribution of productivity improvement to economic growth in each of the mentioned countries in addition to estimating the gap between the available capital stock and the appropriate one in a steady state world. The highest contribution is limited to $1.5 \%$ in Jordan compared with $0.4 \%$ (the lowest) in Syria and the average gap between available and appropriate capital stock exceeds $42 \%$ of GDP.
\end{abstract}

\section{INTRODUCTION}

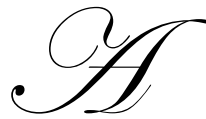

mong the most important reasons of GDP changes is the efficiency of factors of production in addition to capital and labor. Efficiency improvements are called productivity increases. Over time, the same factors of production can produce more output. Productivity increases result from changes in knowledge, as people learn through experience to better perform familiar tasks.

The Solow growth model presents a theoretical framework for understanding the sources of economic growth, and the consequences for long-run growth of changes in the economic environment and in economic policy.

The purpose of this paper is to measure the contribution of the productivity factor into the economic growth of Lebanon, Jordan, Egypt, and Syria. For this purpose, we will estimate the available and appropriatee capital stock in each of the mentioned countries assuming a steady state world.

As no academic work assessing the productivity's contribution to GDP in these four Arab countries has been done, this paper tries to fill this gap using the Solow Model as the main tool for estimating productivity as well as capital stock despite the complete absence of detailed statistics regarding technology, productivity, labors, capital, and savings.

In the first section, the Solow Model framework is reviewed. The second section is conceived to measuring the productivity factors and the available capital stock in each country. The last section assumes the Steady State world and simulates the appropriate capital stock that should be available in Lebanon, Jordan, Egypt, and Syria. 


\section{THE SOLOW MODEL}

\section{Theoretical Framework}

The Solow growth model is reviewed in order to present the long-run relationship and the predictions proposed. The Solow model is based on a neoclassical Cobb-Douglas production function:

$Y_{t}=A_{t} \times\left(K_{t}\right)^{\alpha}\left(L_{t}\right)^{1-\alpha}$

where $\mathrm{Y}$ is output, $\mathrm{K}$ is capital, $\mathrm{L}$ is labor, $\mathrm{A}$ is the level of technology, and $\alpha$ is the income share of capital. It is also assumed that $\mathrm{L}$ and $\mathrm{A}$ grow exogenously at constant rates $\mathrm{n}$ and $\mathrm{g}$, respectively, the depreciation rate is $\delta$ and $\mathrm{s}$ is the constant saving rate. Based on these assumptions Mankiw et al. (1992) ${ }^{1}$ derived the following estimable long-run relationship:

$\ln \left(\frac{Y}{L}\right)=\alpha+\left[\frac{\alpha}{(1-\alpha)}\right] \ln s-\left[\frac{\alpha}{(1-\alpha)}\right] \ln (n+g+\delta)+\varepsilon$

where $\varepsilon$ is the error term of the regression. Equation 2 clearly predicts that the saving rate positively affects output per capita, while the rate of growth of population negatively affects output per capita. In addition, these effects are equal in magnitude.

\section{Empirical Assessment Of Solow Model}

Economic growth research efforts were focused on trying to show whether the predictions of the endogenous growth models were better than the predictions of the Solow model. At the outset, it is expected that the Solow model will capture a large part of the variation in the data since they include the aggregate saving rate, the rate of growth of population and the initial capital, variables that are systematically correlated with economic growth. Mankiw et al. (1992) tested the Solow model and found that its prediction that output per capita is inversely related to the rate of growth of population and positively related to the saving rate (qualitative restriction) is supported by the data. However, the magnitudes of these estimated effects (quantitative restriction) are larger than predicted. Therefore, they augmented the original model by including human capital and in this way they proposed a model that incorporated the most important determinants of economic growth. The augmented Solow model provided qualitative and quantitative predictions that are empirically verified. Hence, the authors conclude that this model gives an excellent description of the cross-country data, especially for the non-oil and intermediate countries.

Even though the Mankiw-Romer-Weil augmented Solow model provides a good description of the growth pattern for non-oil and intermediate countries, it explains less than $30 \%$ of the variation in the data for OECD countries. Nonneman and VanHoudt $(1996)^{2}$ argue that the difference in explanatory power of the augmented Solow model in a broader sample versus the OECD sample is due to the fact that not all the relevant factors of production were included. Therefore, they propose a further augmentation of the Solow model by explicitly including the (endogenous) accumulation of technology know-how. This new model is shown to explain about $75 \%$ of per capita income variation in OECD countries.

The results of the last two papers imply that the framework of the Solow models seems to explain economic growth $^{3}$. One, however, might think that this result is specific to the statistical methodology used by Mankiw et al.

\footnotetext{
${ }^{1}$ Mankiw, N. G., Romer, D. and Weil, D. N. (1992), “A contribution to the empirics of economic growth”, Quarterly Journal of Economics, 107, 407-37.

${ }^{2}$ Nonneman, W. and Vanhoudt, P. (1996), "A further augmentation of the Solow model and the empirics of economic growth for OECD countries”, Quarterly Journal of Economics, 111, 943-53.

${ }^{3}$ Kalaitzidakis P. and Korniotis G.,(2000), "The Solow Growth Model: Vector Autoregression (VAR) and Cross-Section TimeSeries Analysis", Journal of Applied Economics, 32, 739-747
} 
(1992) and Nonneman and VanHoudt (1996), since it is well known that many empirical results were not robust in different frameworks as in the case of Levine and Renelt $(1992)^{4}$, and Sala-i-Martin (1997) $)^{5}$. Further empirical results were presented based on the Solow model that reinforced and complemented those of Mankiw et al. (1992), using a different statistical approach based on Vector Auto-regression (VAR) ${ }^{6}$ and cross-section time-series ${ }^{7}$ frameworks. Under these frameworks, the Solow model can be treated as the long-run relationship derived from statistically adequate short-run models that incorporate dynamics.

In our study, we will not discuss whether the forecast of endogenous growth models are better than the one of the Solow Model; rather, we will base our estimations on Solow Model, assuming that the model is applicable and serves as a good technique to answer the purpose of this study.

\section{MEASURING THE CONTRIBUTION OF PRODUCTIVITY TO GDP}

If we consider a real-world situation in which all three-the capital stock, the labor force, and total factor productivity are changing - then the proportional growth rate of output is:

$\Delta Y / Y t=\alpha \Delta K / K t+(1-\alpha) \Delta L / L t+\Delta A / A t$

with the first term $\alpha(\Delta \mathrm{K} / \mathrm{K})$ giving the contribution of capital to the growth of output, the second term $(1-\alpha)(\Delta \mathrm{L} / \mathrm{L})$ giving the contribution of labor to the growth of output, and the third term $(\Delta \mathrm{A} / \mathrm{A})$ giving the contribution of total factor productivity to the growth of output.Thus, this equation is the key. If we know the proportional growth rates of output, the capital stock, and the labor force, and if we know the diminishing-returns-to-scale parameter $\alpha$ in the production function, then we can use this growth-accounting equation to calculate the rate of growth ${ }^{8}$ of total factor productivity $\mathrm{A}$, and to decompose the growth of total output $\mathrm{Y}$ into:

- $\quad$ The contribution from the increasing capital stock K.

- $\quad$ The contribution from the increasing labor force $\mathrm{L}$.

- $\quad$ The contribution from higher total factor productivity A.

One way to view this growth-accounting equation, is that it allows to break down growth into components that can be attributed to the observable factors of the growth of the capital stock and of the labor force, and to a residual factor - often, in fact, called the Solow residual - that is the portion of growth left unaccounted for by increases in the standard factors of production. Changes in the Solow residual or total factor productivity can come about for many reasons. Economists often refer to total factor productivity as "technology," but if it is technology, it is technology in the widest possible sense ${ }^{9}$.

\footnotetext{
${ }^{4}$ Levine, R. and Renelt, D. (1992), “A sensitivity Analysis of Cross-country Growth Regressions", American Economic Review, 82, 942-64.

${ }^{5}$ Sala-i-Martin, X. (1997), "I just run two million regressions", AEA Papers and Proceedings, 87, 178-83.

${ }^{6}$ The VAR analysis, based on G7 countries, revealed that output per capita, the saving rate and the rate of growth of population are cointegrated for all countries except the UK and Canada. The five cointegrated relationships support the qualitative restriction but the estimated income share of capital is on average 0.64 which is greater than the observed value, one third. Hence, the data reject the quantitative restriction set by the Solow model. In addition, it is argued that output per capita is weakly exogenous with regard to the long-run relationship whereas the exogeneity of the investment rate and the rate of growth of population is unclear.

${ }^{7}$ The cross-section time-series analysis of the Solow model for the USA, Japan and Germany (G3 countries) showed that the combined model describing the three countries is the fixed effect model. We also found that the estimated long-run relationship supports the qualitative and not the quantitative restriction. In addition, the income share, estimated by this long-run relationship (with the qualitative restriction imposed), is equal to 0.67 , which is much greater than the observed value.

${ }^{8}$ Not directly observed.

${ }^{9}$ It is not just new ways of constructing buildings, newly invented machines, and new sources of power that affect total factor productivity, rather, it is about changes in work organization, in the efficiency of government regulation, in the degree of monopoly in the economy, in the literacy and skills of the workforce, and in many other factors.
} 
Moreover, total factor productivity also inherits errors in measurement. An overstatement of inflation because of a failure to take account of better quality in goods will reduce the measured growth rate of output without reducing the measured growth rates of the inputs of labor and capital, and so will lead measured total factor productivity to understate the truth.

An alternative way of writing the growth-accounting framework puts the rate of growth of output per worker, the growth rate of output minus the growth rate of labor input - on the left-hand side. The key variables on the right hand side are then the growth rate of capital-per-worker and of total factor productivity:

$\Delta Y / Y t-\Delta L / L t=\alpha(\Delta K / K t-\Delta L / L t)+\Delta A / A t$

This expression ${ }^{10}$ decomposes the growth of labor productivity into two terms: $\alpha(\Delta \mathrm{K} / \mathrm{K}-\Delta \mathrm{L} / \mathrm{L})$ gives the contribution of capital deepening to increased labor productivity, and $(\Delta \mathrm{A} / \mathrm{A})$ gives the contribution of total factor productivity to the growth of labor productivity.

In this section and far from any pretentiousness in percentages' accuracy, due to the serious lack in secondary information regarding the countries in question, we will try to estimate and compare in a first step the available capital stock in each of the four countries.

\section{Estimation Of The Available Capital Stock}

As we have mentioned, and due to the absence of statistics, and in order to estimate the available capital stock, $k_{t}$, as a percentage of GDP, we will focus on the average dollar value of imports in each country (imports of machinery and equipments) and their structure, and on the average amount of government's expenditures in the budget on capital stock. The average would cover 5-year period (1999-2004) and would be divided by the average GDP over the same period. Table 1 summarizes the average capital stock in each country as a percentage of the average GDP for the period 1999-2004.

Table 1: Average Capital Stock To Average GDP

\begin{tabular}{|c|c|}
\hline Country & $\frac{\bar{K}}{\overline{G D P}}$ \\
\hline Lebanon $^{11}$ & $12 \%$ \\
\hline Jordan & $13 \%$ \\
\hline Egypt & $16 \%$ \\
\hline Syria & $10.5 \%$ \\
\hline
\end{tabular}

\section{The Contribution Of Productivity To The Economic Growth}

Since the countries we are studying has 25 to 30 percent of there population below poverty line and since GDP per capita is relatively very low, it would be reasonable to assume that the income earned is mostly consumed. Therefore, consumption has the largest share of income, say $\mathrm{C}=95 \%$. We assume as well that what is saved (5\%) is totally invested.

\footnotetext{
${ }^{10}$ Since we are usually at least as interested in the growth of standards of living and output per worker as in the growth rate of total GDP, this form of the growth-accounting framework is often more useful.

${ }^{11}$ For more details about Lebanon, see Naïmy V. (2004). "A proposed Restricting of Lebanese Public Debt To Promote Economic Growth". The International Business And Economics Research Journal, Volume 3, Number 8, p15-25.

Naïmy V. (2003). "Marchés Emergents, financement des PME et croissance Economiques: Etude du cas libanais », NDU Press.
} 
Figure 1: Estimated $\mathbf{K}_{\mathbf{t}}$

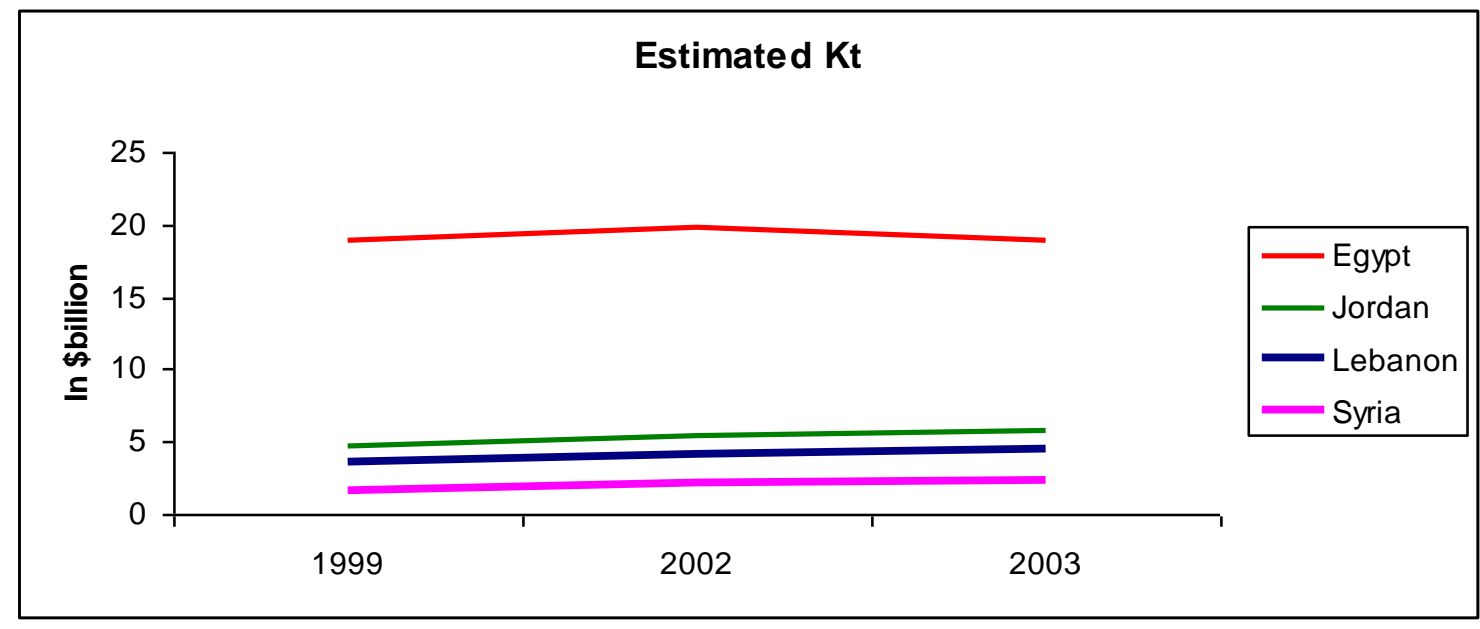

We will use the per worker notation, where:

$\mathrm{y}_{\mathrm{t}}=\mathrm{Y}_{\mathrm{t}} / \mathrm{L}_{\mathrm{t}}$, output per worker in period $\mathrm{t}$,

$\mathrm{c}_{\mathrm{t}}=\mathrm{C}_{\mathrm{t}} / \mathrm{L}_{\mathrm{t}}$, consumption per worker in period $\mathrm{t}$,

$\mathrm{k}_{\mathrm{t}}=\mathrm{K}_{\mathrm{t}} / \mathrm{L}_{\mathrm{t}}$, investment per worker in period $\mathrm{t}$.

Figure 2 shows the population growth in each of the four countries for the period 1999-2003.

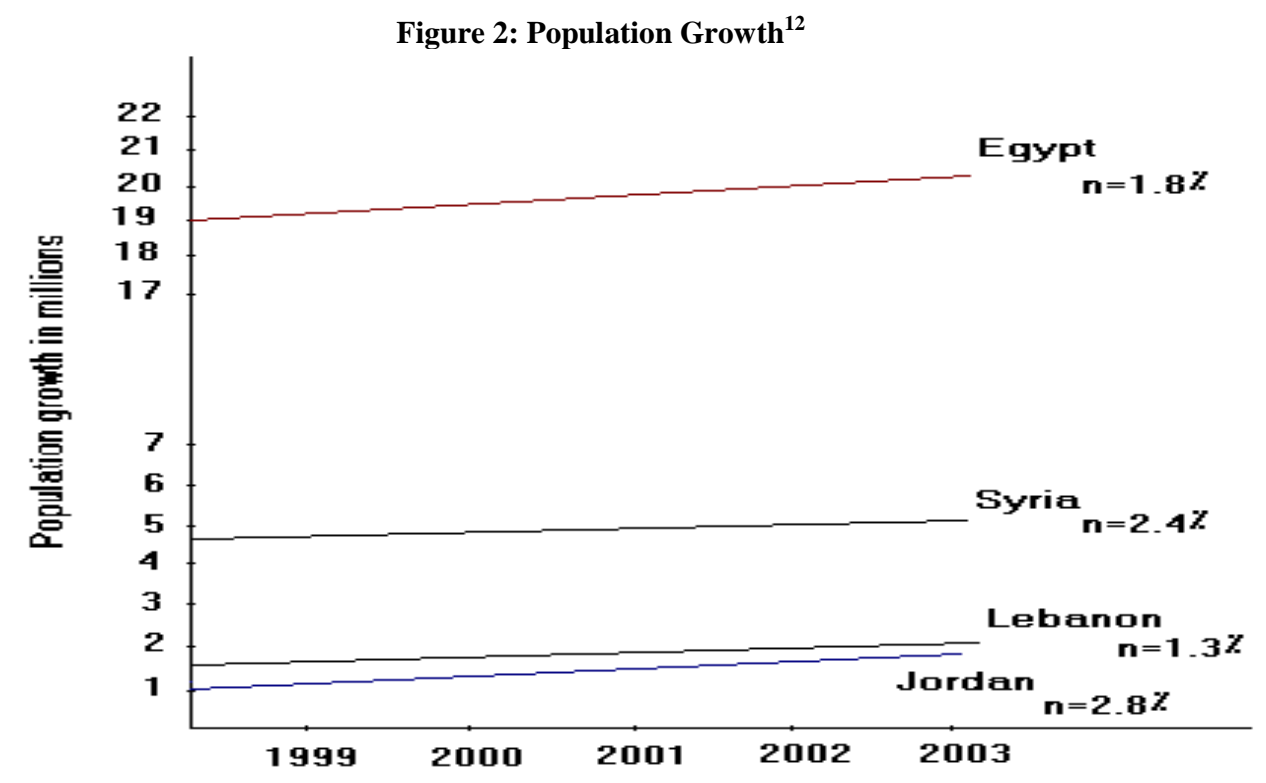

${ }^{12}$ http://www.worldbank.com 
Table 2 depicts the per worker five variables, $\mathrm{y}_{\mathrm{t}}, \mathrm{c}_{\mathrm{t}}, \mathrm{k}_{\mathrm{t}}, \mathrm{I}_{\mathrm{t}}$ (in USD) for each of the four countries over the selected period: 1999, 2002, and 2003

Table 2: Calculation of $y_{t}, c_{t}, k_{t}$, and $I_{t}$

\begin{tabular}{|c|c|c|c|c|c|c|c|c|c|c|c|c|}
\hline \multirow{2}{*}{ Country } & \multicolumn{4}{|c|}{1999} & \multicolumn{4}{|c|}{2002} & \multicolumn{4}{|c|}{2003} \\
\hline & $\mathbf{y}_{\mathrm{t}}$ & $c_{t}$ & $\mathbf{k}_{\mathrm{t}}$ & $I_{t}$ & $\mathbf{y}_{\mathbf{t}}$ & $c_{t}$ & $\mathbf{k}_{\mathbf{t}}$ & $\mathbf{I}_{\mathrm{t}}$ & $\mathbf{y}_{\mathbf{t}}$ & $c_{t}$ & $\mathbf{k}_{\mathrm{t}}$ & $\mathbf{I}$ \\
\hline Lebanon & 11000 & 10450 & 1333 & 650 & 11090 & 10535 & 1346 & 555 & 11520 & 10943 & 1380 & 577 \\
\hline Jordan & 7013 & 6690 & 913 & 323 & 7966 & 7567 & 976 & 399 & 8182 & 7772 & 1007 & 410 \\
\hline Egypt & 4690 & 4455 & 750 & 235 & 4638 & 4406 & 719 & 232 & 4182 & 3972 & 646 & 210 \\
\hline Syria & 3312 & 3147 & 348 & 165 & 3864 & 3670 & 427 & 194 & 4274 & 3875 & 450 & 399 \\
\hline
\end{tabular}

Based on the production function as expressed in equation (3), we will analyze sources of growth in each of the above mentioned countries through increases in inputs and productivity. Therefore, measuring the growth rates of output, $\Delta \mathrm{Y} / \mathrm{Y}$, of capital, $\Delta \mathrm{K} / \mathrm{K}$, and labor, $\Delta \mathrm{L} / \mathrm{L}$, for each economy constitutes the first step of analyzing the structure of growth for the period 2002-2003. With reference to data displayed in table 1 and 2 and based on secondary information available from the World Bank, we reached the following results for each of the following four countries:

Table 3: Application of Equation (3) $\Delta \mathrm{Y} / \mathrm{Y}_{\mathrm{t}}=\alpha \Delta \mathrm{K} / \mathrm{K}_{\mathrm{t}}+(1-\alpha) \Delta \mathrm{L} / \mathrm{L}_{\mathrm{t}}+\Delta \mathrm{A} / \mathrm{A}_{\mathrm{t}}$

\begin{tabular}{|l|c|c|c|c|c|}
\hline Country & $\Delta \mathbf{Y} / \mathbf{Y}$ & $\square \Delta \mathbf{L} / \mathbf{L}$ & $\Delta \mathbf{K} / \mathbf{K}^{\mathbf{1 3}}$ & $\mathbf{( 1 - \alpha )}^{\mathbf{1 4}} \Delta \mathbf{K} / \mathbf{K}$ & $(\boldsymbol{\alpha}) \Delta \mathbf{L} / \mathbf{L}$ \\
\hline Lebanon & $3.3 \%$ & $1.3 \%$ & $3.3 \%$ (based on our est. $^{15}$ ). & $=0.6 \times 3.3 \%=1.98 \%$ & $=0.4 \times 1.3 \%=0.52 \%$. \\
\hline Jordan & $6.3 \%$ & $2.54 \%$ & $6.3 \%$ & $=0.6 \times 6.3 \%=3.78$ & $=0.4 \times 2.5 \%=1 \%$ \\
\hline Egypt & $3.2 \%$ & $1.65 \%$ & $3.2 \%$ & $=0.6 \times 3.2 \%=1.92 \%$ & $=0.4 \times 1.65 \%=0.66 \%$ \\
\hline Syria & $=3.2 \%$ & $2.2 \%$ & $3.2 \%$ & $=0.6 \times 3.2 \%=1.92 \%$ & $=0.4 \times 2.2 \%=0.88 \%$ \\
\hline
\end{tabular}

Based on table 3, we can deduce the contribution of productivity growth to economic growth in each of the four countries.

Lebanon: $\Delta \mathrm{A} / \mathrm{A}=3.3 \%-1.98 \%-0.52 \%=0.8 \%$.
- $\quad$ Jordan: $\Delta \mathrm{A} / \mathrm{A}=6.3 \%-3.78 \%-1 \%=1.52 \%$.
Egypt: $\Delta \mathrm{A} / \mathrm{A}=3.2 \%-1.92 \%-0.66 \%=0.62 \%$.
-

\footnotetext{
${ }^{13}$ We previously assumed in our calculations of available capital stock that it is measured as a percentage of GDP, consequently, it should grow by the same percentage growth as GDP.

${ }^{14} \mathrm{We}$ assume in these four developing countries that $\alpha=0.4$ (which is greater than any average value in advanced countries). Any increase in capital stock in these countries will have a greater effect than advanced countries and eventually will lead to a significant increase in output.

${ }^{15}$ Please refer to section II-1 and II-2
} 
Figure 3: Contribution Of Each Factor To Economic Growth

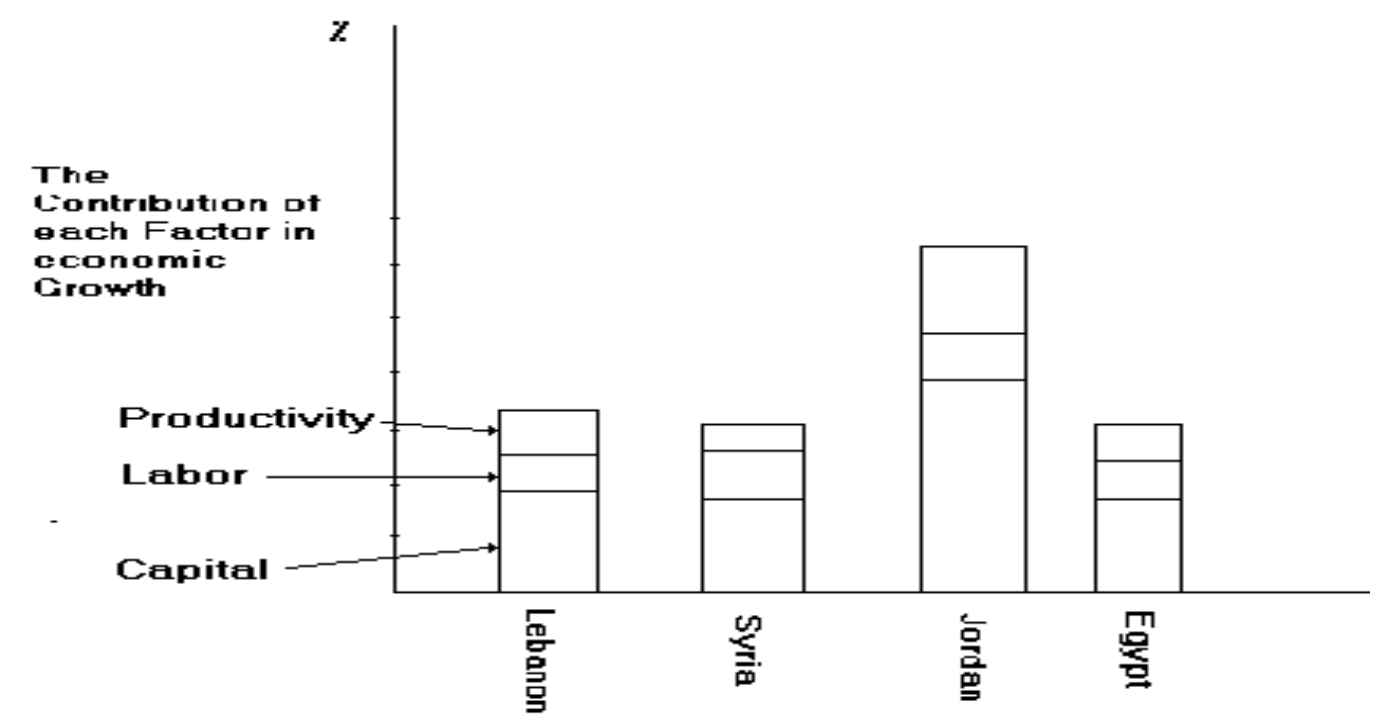

\section{REACHING STEADY STATE AND CALCULATING THE APPROPRIATE CAPITAL STOCK}

In this section, we will assume the presence of a steady state ${ }^{16}$ world in each of the four countries under analysis in order to predict the appropriate capital stock that should be available in each of these countries. This assumption is definitely not realistic; however, we will use it as a benchmark or simply as an indicator to show the huge difference between the average available $\mathrm{K}_{\mathrm{t}}$ and the appropriate one in a steady state world. We have already assumed that savings represent a very small share of income about $5 \%$ of income. $S_{t}=s Y_{t}$ where $s$ is the saving rate in every year $\mathrm{t}$. We also assumed that national savings $\mathrm{S}_{\mathrm{t}}=\mathrm{I}_{\mathrm{t}}$, investment. Therefore, in a steady state world we have:

$s Y_{t}=(n+\delta) K_{t}$

where $\mathrm{n}$ and $\delta$ are defined in equation (2) and are assumed to be as illustrated in table 4.

Table 4: n And $\delta$ In Each Of The Four Countries

\begin{tabular}{|c|c|c|}
\hline Country & $\mathbf{n}(\mathbf{\%})$ & $\boldsymbol{\delta}(\mathbf{\% )}$ \\
\hline Lebanon $^{17}$ & 1.3 & 7 \\
\hline Jordan & 2.4 & 7 \\
\hline Egypt & 2.8 & 7 \\
\hline Syria & 1.8 & 7 \\
\hline
\end{tabular}

\footnotetext{
${ }^{16}$ A steady state is a situation in which the economy's output per worker, consumption per worker, capital per worker are constant, i.e. in a steady state, yt, ct, and kt do not change over time.

${ }^{17}$ For deeper analysis regarding $n$ in Lebanon see Naimy V. (2005), “Unemployment in Lebanon: Application Of Okun's Law”. The Journal of Business and Economics Research, to appear in October 2005 issue.
} 
world.

Applying equation (5) for each country will help to estimate the appropriate capital stock in a steady state

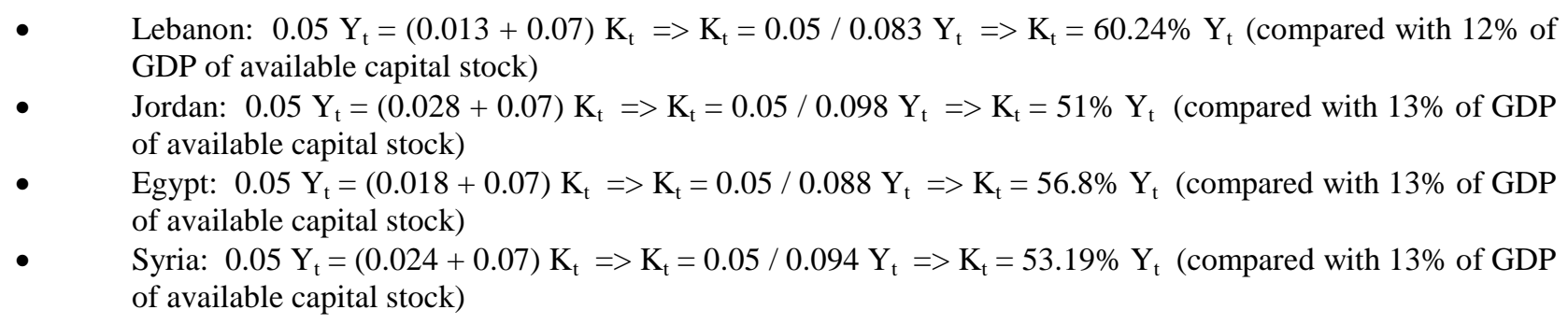

\section{CONCLUSION}

Despite the very restrictive hypothesis that we have set in order to measure the productivity growth in Lebanon, Jordan, Egypt, and Syria and its contribution to economic growth, we were able to obtain very convincing results in harmony with the current situation of these four countries. We got serious productivity growth slowdown. The highest one was below 1.5\%. Possible reasons behind this low productivity growth rates are: (1) Measurement problems unable to capture changes in quality, (2) political, legal, and human environment where more inputs are devoted to these uses, hence output and productivity will be lower. In addition, rising dishonesty, terrorism, crimes and corruption have reduced the measure, (3) delayed technology where the major technological advances have not been utilized and new commercially significant technological advances have not arrived fast enough to these countries, (4) oil price rise that makes many energy intensive machines and factories unprofitable to operate and so nation's capital stock fell by more than is reported.

The huge difference between available and appropriate capital stock in each country, with an average gap of $42.25 \%$, explains to some extent the noteworthy slow down in productivity where Lebanon has the highest gap and Jordan the lowest one. These percentages are highly correlated with the average percentage growth of productivity where Jordan has also the highest level and Syria the lowest with a small difference of $0.4 \%$ for Lebanon's productivity growth. These countries should urgently take measures to encourage investment, improve productivity, create jobs, and particularly increase the standard of living. However, in order to reach these objectives, each of the studied country should implement proper internal domestic reforms in the financial, regulatory, political, and legal environments including access to credit, efficient judicial taxation, and customs systems. Lengthy bureaucratic procedures, unclear regulations, and corruption, pose major obstacles to productivity, economic growth development, and integration into global markets.

\section{BIBLIOGRAPHY}

1. Barro, R. (1991), Economic Growth in a Cross-section of Countries, Quarterly Journal of Economics, 106, 407-44.

2. Central Bank of Jordan Bulletins (1999-2005)

3. Central Bank of Lebanon Monthly Bulletins (1999-2005)

4. Cigno, A. and Rosati, F. (1996), Jointly Determined Saving and Fertility Behaviour Theory, and Estimates for Germany, Italy, UK and USA, European Economic Review, 40, 1561-89.

5. Dickey, D. A. and Fuller, W. A. (1979), Distributions of the Estimators for Autoregressive Time Series With a Unit Root, Journal of the American Statistical Association, 74, 427-31.

6. Johansen, S. (1988), Statistical Analysis of Cointegrating Vectors, Journal of Economic Dynamics and Control, 12, 231-54.

7. Johansen, S. (1991), Estimation and Hypothesis Testing of Cointegration in Gaussian Vector Autoregressive Models, Econometrica, 59, 1551-80.

8. Kalaitzidakis P. and Korniotis G.,(2000), The Solow Growth Model: Vector Autoregression (VAR) and Cross-Section Time-Series Analysis, Journal of Applied Economics, 32, 739-747. 
9. Levine, R. and Renelt, D. (1992), A sensitivity Analysis of Cross-country Growth Regressions, American Economic Review, 82, 942-64.

10. Mankiw, N. G., Romer, D., and Weil, D. N. (1992), A Contribution To The Empirics of Economic Growth, Quarterly Journal of Economics, 107, 407-37.

11. Naïmy V. (2003), Marchés émergents, financement des PME et croissance économique: étude du cas libanais NDU Press.

12. Naïmy V. (2004), Financing Problems Faced By The Lebanese SMEs: An Empirical Study. The International Business And Economics Research Journal, Volume 3, Number 1, January, pp. 27-38.

13. Naïmy V. (2004). A proposed Restricting of Lebanese Public Debt To Promote Economic Growth. The International Business And Economics Research Journal, Volume 3, Number 8, p15-25.

14. Naimy V. (2005), Measuring the Effect of Financial Liberalization On The Supply Of Credit To The Private Sector: The Case Of Lebanon. The International Business And Economics Research Journal, ISSN 15350754, Volume 4, Number 5, May 2005, p. 17-30.

15. Naimy V. (2005), Unemployment in Lebanon: Application Of Okun's Law. The Journal of Business and Economics Research, to appear in October 2005 issue.

16. Nonneman, W. and Vanhoudt, P. (1996), A further Augmentation of the Solow Model and the Empirics of Economic Growth for OECD Countries, Quarterly Journal of Economics, 111, 943-53.

17. Sala-i-Martin, X. (1997), I just run two million regressions, AEA Papers and Proceedings, 87, 178-83.

18. Temple, J. (1999), The New Growth Evidence, Journal of Economic Literature, 37, 112-56.

19. www.finance.gov.lb

20. $\quad$ www.jordanembassyus.org

21. www.Mideastweb.com

22. www.state.gov

23. www.worldbank.com 


\section{NOTES}

